\title{
A mídia, a democracia e o tempo*
}

\section{RESUMO}

Para Lucien Sfez, se existem dois ou vários tempos diversificados, esta oposição é menos radical do que parece. Trata-se, preferencialmente, de um jogo complexo de diferenças que afetam as temporalidades, tanto da mídia como aquelas da democracia vivida pelos cidadãos. Segundo o autor, entra em cena, agora, o tempo das mídias, que ganha força na contemporaneidade. Mas, como situá-lo? É isso que Sfez procura equacionar.

\section{PALAVRAS-CHAVE}

mídia

sociedade

imprensa

\begin{abstract}
This paper deals with pertinent topics to the communication process, like the spirit technological manifestations in the communicational field, the communication strategies cread to fill the existing gap among great ideologies, the search for perfect health -extensive to the area of technology and communication - as the new utopic paradigm of XXI Century as well as the comprehension of technology as a speech and communication narrative, from the dialogue with the researcher and thinker Lucien Sfez.
\end{abstract}

\section{KEY WORDS}

media

society

press

\section{Lucien Sfez}

Universidade de Paris I Panthéon Sorbonne
A rapidez das transmissões, o fluxo incessante,, o fluxo incessante, e mesmo incontrolável das informações, tudo isso parece ser a característica da época contemporânea, que se pode chamar de reino da mídia. O tempo da mídia se oporia completamente à gestão tradicional do tempo vivido, sacudindo, assim, a ordem das coisas. Isto é dito e repetido de todas as formas. São clichês que cada um se apressa em transmitir.

Ora, esta oposição de duas temporalidades, em que uma engole a outra, já estava na moda há 20 anos, e mesmo há 30... Como prova, apresentarei uma revista que encontrei nos meus arquivos: é um número de "Projet", de 1975, intitulado La société Chronophage. Dois tempos se devoram entre si. A luta entre o aion (o eterno presente do pensamento) e a sombra chronos (fato de instantes sucessivos que se apagam uns em relação aos outros).

É verdade que nos anos 70 a mídia não tinha alcançado a força que tem hoje em dia, e que as análises insistiam preferencialmente na uniformização de um tempo de trabalho mecânico, na banalização dos tempos de lazer e na catástrofe para a vida de espírito que este estado de coisas devia produzir. E quando esta oposição toma ares de um combate maniqueísta entre um Golias megalômano e midiático e um David modesto e cidadão!

Na verdade, se há dois ou mesmo vários tempos, diversificados, a oposição é menos radical do que parece. Trata-se, preferencialmente, de um jogo complexo de diferenças que afetam as temporalidades, quer sejam aquelas da mídia (pois não é correto pensar que o tempo da mídia é único e duradouro) ou aquelas da democracia tal como ela vivida pelos cidadãos (pois, neste caso também, as temporalidades variam segundo a idade, a classe social, as funções ou as instituições).

Assim, à oposição velocidade/lentidão, imediatismo/ atraso, continuidade/descontinuidade somam-se diferenças de regimes e de registros. Acrescentemos, também, que os elementos de cada par não deixam de se influenciar mutuamente, e nós teremos uma idéia da impossibilidade de uma oposição tão drástica. Para escapar da simplificação habitual e de uma complicação inútil, eu proporia o exame das temporalidades democráticas tais quais elas se apresentam a nós na vida civil.

Mas antes de começar esta análise, proponho uma reflexão sobre duas noções-chave do problema da temporalidade: $\mathrm{O}$ rito e o ritmo ${ }^{1}$.

\section{0 rito e o ritmo}

Aristóteles dizia que o tempo era "o número do movimento"2.

Foi preciso que tivesse movimento para que houvesse tempo; quer seja a sucessão do dia e da noite, aquela das estações, ou o ciclo dos astros, o movimento da Terra. $\mathrm{O}$ 
movimento estabelece a ligação do espaço (no qual o movimento se produz) e do tempo que escande este movimento. Escansão que permite a medida - do tempo que se escoa entre início e fim do movimento -, medida que permite a tomada de consciência da mudança. Dito de outra forma, se ele não é escandido nós não temos qualquer consciência do tempo passado. (É Aristóteles, ainda, que nos conta a história das pessoas adormecidas perto de Sardes e que acordam depois de 50 anos: nada havia mudado para elas, pois não tinham nenhuma consciência do tempo consumido) ${ }^{3}$.

Os grupos humanos, mesmo os mais distantes na história, conhecem perfeitamente esta lei e a jogam com habilidade: escandir o tempo é medi-lo, e medi-lo é governá-lo. Ora, o que é dominar o tempo senão regrar o modo de vida dos indivíduos e dos grupos, dos clãs, das tribos e dos povos? Toda política que se pretende nova começa por uma transformação (dita reforma) do calendário; quer se trate de renomear os meses e as estações do ano, de contar o número de dias, de decidir sobre feriados ou dias de trabalho.

\section{Os calendários}

Comecemos com alguns exemplos gritantes. O primeiro é o de Clístenes, o ateniense, que decidiu instituir um calendário político distinto do calendário religioso, o único, até então, conhecido. Ao fazê-lo, ele pontuava que a política devia seguir seu caminho independentemente da religião e dos seus ritos. Mas ele pontuava, também, que a política devia ter seu ritmo e que não podia estabelecer o ritmo do tempo4. Paralelamente, ele instituía um outro corte do espaço de Ática, dividindo-o em três partes: cidade, costa e interior, cada tribo formada de três "trittye", pertencendo aos três setores divididos daquela forma. A repartição é homogênea: espaço e tempo redesenhados formam a base da democracia ateniense.

Ao mesmo tempo em que o novo calendário político (o calendário pritânico) foi justaposto ao da religião (calendário lunar), a Boulé, a câmara das deliberações, foi construída ao lado do velho templo de Deméter, junto à Acrópole. O novo rito ao lado do rito antigo, duas ritualizações lado a lado. Assim, o tempo político da democracia tornou independente as fases da lua ou as decisões arbitrárias do arconte. Para uma tribo, "ter a pritania" é administrar a cidade, ocupar um espaço (o fórum comum) e um tempo político: $\mathrm{o}$ ano pritânico. Este exemplo não é escolhido ao acaso: o nascimento e a manutenção da democracia devem mais do que se crê às contribuições do espaço e do tempo. O ritmo calendular impõe não apenas paradas e partidas, repouso e trabalho, mas a origem religiosa do calendário: os ritos, mesmo políticos, são filhos do ritmo, que serve para marcar as escansões de maneira única, com a ajuda das imagens. Clístenes, que é ocidental para nós e o inventor da democracia ateniense, nos mostra, aqui, o caminho.

Segundo exemplo: César, diante da desordem e da arbitrariedade do calendário romano de então, decide reagir. Na verdade, os Pontífices regulavam o calendário segundo seu bel-prazer: datas das eleições, duração das magistraturas, cobranças do fisco. A dominação do calendário era um instrumento de corrupção inevitável. Por causa de seus abusos, chegava-se até a celebrar os Outonalia e a colheita em pleno inverno... César procurou dar uma forma única e legal a um calendário mais abstrato, igualitário, que não levava mais em conta os pontífices: o calendário Juliano5.

Ainda outro recurso em reformar o calendário: a Revolução Francesa e seu novo calendário universal. Data de 1792, e se aplicou durante 12 anos, depois abolido por Napoleão, em 1805. Seus autores tinham ignorado, diz Paul Couderc, "a força possante dos aniversários no coração dos homens". Ele precedia a decupagem do espaço francês em departamentos. Tempos e espaço unidos, e ritmos, mais uma vez aqui, ligados aos ritos (novas festas, novos dias feriados, que não tinham, todavia, tido tempo de entrar no espírito dos cidadãos).

Atualmente, nós vivemos com dois calendários, o laico e o religioso, sem que isso nos coloque grandes problemas: eles se sobrepõem e se harmonizam, ritmando, igualmente, o tempo de trabalho e o de lazer. Mais o que é feito de um novo tempo, chamado "tempo da mídia"? Onde ele se inscreve? De qual lado deste calendário dobrado o novo tempo se situa? Esse novo tempo faz parte de uma revolução que também transforma o espaço? Ele se junta ao tempo já ritualizado e ritmado ou instaura, pelo contrário, uma ritualização e um ritmo que se oporiam ao primeiro?

Para tratar desta questão, tentarei mostrar sucessivamente de que forma as duas temporalidades, da mídia e da democracia, se opõem (primeira parte) e como, na prática, elas interagem (segunda parte).

\section{Democracia e mídia: os tempos que se opõem}

As temporalidades da democracia parecem não ter nada a ver com as da mídia. Aparentemente, elas são antípodas. Nós apresentaremos, pois, sucessivamente, o tempo da democracia (A), e o tempo da mídia (B).

\section{A) 0 tempo e a democracia}

São os tempos de remissões, de procedimentos, de discussões regradas, alcançando resultados, decisões. Tempos justapostos que não têm nada em comum, mas que, porém, se produzem simultaneamente e que andam juntos, coordenados por instâncias centrais ou descentralizadas. Só o tempo judiciário escapa à condição administrativa por causa do uso de regras próprias.

O calendário das eleições não corresponde ao calendário judiciário ou à agenda das grandes decisões de foro econômico. Também há o tempo escolar (que não é o da universidade), o tempo das férias e das grandes migrações turísticas. O governo se ocupa do tempo do trabalho, de seu gerenciamento, de seu controle. Tenta coordenar o tempo das populações, das diferentes profissões (não esqueçamos os guerreiros que trabalham 
mais de 60 horas por semana).

Não se nasce democrata. Torna-se um por causa de uma série de tentativas e erros. A constituição do sujeito e a do Estado leva tempo: o tempo de maturação, lá onde a memória e a história alimentam a razão. Lá onde as instâncias políticas e administrativas criam plataformas e comissões.

\section{B) Os tempos de uma vila}

Para dar uma idéia das disparidades do tempo democrático e do papel da história, eu gostaria de apresentar alguns elementos de uma pesquisa feita em 1980 sobre os diferentes tempos em um lugarejo dos Alpes Marítimos, situado acima de Nice: Carros, bem conhecido na França por seus belos morangos ${ }^{6}$.

Tratava-se, nesta pesquisa, de testar a solidariedade efetiva que devia levar à instauração dos sindicatos intercomunais entre as vilas próximas. Pergunta-se: estes lugarejos estavam prontos em unir seus interesses e entrar em acordo sobre um modo de gestão e um modo de desenvolvimento de suas comunidades? Tinham preocupações comuns? O que pensavam os atores sociais a respeito solidariedade: solidariedade de quem, em nome do quê, para quê e contra o quê? A demanda vinha da administração, que, apesar de conhecer os mecanismos institucionais (que ela própria havia colocado em prática), ignorava zonas ocultas, subjacentes em que trabalhavam as populações e se manifestavam, às vezes, por fortes oposições, rejeições ou conflitos cuja causa parecia ignorada.

O projeto consistia, pois, em estudar bem de perto, quase microsociologicamente, as relações de solidariedade (ou não) em um lugar circunscrito, onde nós poderíamos passar bastante tempo para que nos impregnássemos da vida íntima dos habitantes. Depois de muitas hesitações - era preciso que tivéssemos "passes", cumplicidade com a localidade para este tipo de trabalho, e também encontrar um problema real, cristalizado, formulado que exigisse uma solução para pôr em ação as solidariedades, ou não. Escolhemos Carros porque essa vila apresentava as características que nós procurávamos. Velho lugarejo da Idade Média, Carros cresceu de repente, e se tornou Carros-Nova, o que nos remetia a uma atmosfera tensa entre as diversas partes da comunidade, sem contar os problemas que Carros tinha com as vilas próximas.

Nós encontramos grandes divisões entre as classes de idade, os estratos sucessivos de ocupação de terra, as origens dos habitantes do território provençal, e também italianos, enfim turcos e magrebins; divisão que se manifestava também espacialmente pela repartição da vila em três ou mesmo quatro territórios bem demarcados.

Duas questões se colocam: qual unidade podia ser obtida e, se ela fosse impossível, o que, segundo eles, impedia a unificação identitária? Logo ao chegarmos um projeto sindical intercomunal tinha malogrado: as duas comunidades vizinhas de Carros tinham refutado uma aliança em torno do projeto de construção de uma nova cidade, Carros-Nova, com uma zona industrial que ficaria localizada perto de Var, na cidade velha, e Carros-Velha. Carros estava sozinha nesse projeto, ajudada, claro, pela administração, a Prefeitura, o Conselho Geral, em suma as instituições. E já nesta etapa nós percebemos o peso da memória ancestral em todo esse negócio.

Escutemos, antes, esta história: ela nos remete à Idade Média, dos castelos e dos "senhores"... das afrontas e dos ferimentos pela honra... Dois lugarejos vizinhos, um chamado Gattières, não eram opostos mas um não se decidia pelo outro. Le Broc tinha todas as razões do mundo para recusar uma aliança. Por quê? Porque no século XV, o senhor de Carros matou o chefe dos soldados de Broc. Bastante irritados, os brocenses pediram que o rei René arbitrasse o problema. E saiu um edital: de agora em diante, 1/7 das terras de Carros pertenceriam à Broc. Animosidade dos Carrosenses. Contestação até o último instante à Corte de Apelo de Aix, em 1926, que deu razão aos brocenses. Estas terras lhes pertenciam. Mas os carrosenses não queriam saber disso. Um prefeito comunista alugava estas terras como se elas lhe pertencessem.

Ora, estas terras são uma das peças centrais do affaire: na Revolução, os senhores de Broc, os Bracas, foram privados destas terras pela comunidade. Seus herdeiros, hoje, os Lafourcade, moram em Auvergne. O prefeito atual queria estes territórios Lafourcade, da mesma forma que as terras da comuna de Broc. Por quê? Justamente para instalar uma zona artesanal, vizinha à área industrial de Carros-Nova, localizada a meio caminho entre as duas.

Ele negocia com bastante facilidade com o velho prefeito de Broc, interessado em parar com aquela disputa. Le Broc vendeu sua parte por um valor insignificante (36 milhões de francos). Quanto aos Lafourcade, o prefeito lhes fez a corte durante oito anos, visitando-os em seu Castelo de Auvergne. Então, ele os convencera: em troca de sua parte, ele lhes oferece um terreno para a construção de várias vilas. Eles aceitam. De agora em diante, o terreno está limpo para se fazer o novo projeto.

Colocou-se, pois, o dispositivo da zona industrial. Nesse meio tempo, a partir de 1966, data da decisão do Conselho Geral, a nova cidade de Carros foi construída.

Existem, então, diversas Carros :

- A vila antiga;

- As residências secundárias, todas próximas, chamadas "Ecarts";

- Os planos de Carros (agricultura da parte da geração de italianos que fugiram do fascismo, e seus descendentes);

- Carros-Nova com habitações populares e casas Phénix, bem separadas;

- A zona industrial mais recente.

Todas estas Carros possuem temporalidades diferen- 
tes, inclusive a mais alta temporalidade histórica. Todas têm seu próprio ritmo: o ritmo da produção hortifrutigranjeira de Carros, veloz, por causa dos legumes que devem ser entregues todos os dias, não é o dos habitantes da velha cidade, lenta, que vive do passado. $\mathrm{O}$ da produção industrial de Var é ainda diferente: é aquela de uma continuidade mecânica que não se preocupa com as estações e nem com os hábitos da localidade em que foi implantada. Quanto ao tempo nas habitações populares, não é nem o da velha Carros, nem dos granjeiros, menos ainda das indústrias de Var, mas um turbilhão, dividido entre as comunidades nas quais os ritos não são os mesmos.

É o Estado, na pessoa do Prefeito, e por meio de diferentes serviços da administração, que faz estas diferentes temporalidades. As questões litigiosas se negociam. O Prefeito é o grande caçador diante do Eterno, da mesma forma que o prefeito da comuna (ainda um rito!). Não se sabe com antecedência como ficarão as coisas na democracia. São estabilidades sempre provisórias, pragmáticas, que têm pouco a ver com o consenso da razão tradicional, exceto de uma outra razão, a razão razoável, fluida, lábil nas suas retóricas e efeitos.

\section{C) 0 tempo das mídias}

O tempo das mídias parece os antípodas de suas opacidades. Seu fluxo de chegada é contínuo, dia e noite. Capta-se sem trégua as ondas, as vozes, as imagens, tudo isso vindo por todo lado, sem contar a Internet. "A jornada midiática não termina nunca: não tem começo nem fim"7. Além disso, as mídias apagam o imediato e a presença; na verdade, o que elas entendem por presente, a atualidade do dia, da hora, e mesmo do minuto (quando a transmissão é ao vivo), este presente não é a presença, nem o imediatismo da relação entre o indivíduo e seu tempo. O "presente" da atualidade é um tempo mediado, diverso. A presença, em compensação, é uma consciência íntima do ritmo temporal, é ato, espera mobilizadora, aspiração em direção a... É o que nos diz Henri Lefebvre $^{8}$, retomando a análise de Husser $l^{9}$, para o quem o tempo se experimenta através de uma "pro-tensão" anterior, uma espécie de apelo. Ora, o tempo das mídias, contínuo e veloz, não permite que o tempo se constitua. O tempo das mídias é, contrariamente ao que se pensa, "a" ou "antitemporal", ele é "a" ou "anti-presencial".

Contínuo, ele é também repetitivo, e cuja repetição nos dá prazer. Apesar das diferenças e variações que despertam interesse, o mundo, em suma, é sempre o mesmo; o real é, neste caso, reafirmado (inclusive o prazer obscuro do "que chato, é sempre a mesma coisa", justamente pela descontinuidade das variações).

Outra característica: o tempo das mídias é igualmente dilatado (um assunto pode se arrastar durante meses, alimentando assim a repetição) e reduzido: pode-se apresentar, à vontade, o interrogatório de Clinton por oito, quatro horas ou três minutos. Repetitivo, contínuo, como um fluxo irrepreensível, o tempo das mídias, por causa da continuidade incessante das notícias, seria, pois, arrítmico e inteiramente desritualizado.

Abstratamente, pode-se, assim, analisar o tempo das mídias em termos de desritualização. Todavia, desde que o vejamos um pouco mais de perto, é preciso contemporizar esta afirmação: existem ritos nas mídias, como os momentos ritualizados que correspondem à chegada e à apresentação das notícias: o formato e a formatação das sequiências do telejornal também o são. Desta forma, seria preciso antes caracterizar este tempo fora do tempo que é o tempo midiático como o rito sem ritmo. Pois o tempo é fragmentado em "fatias de horários" que pontuam os momentos do dia, e estas fatias são ritualizadas pela mídia e pelo público; esta ritualização não se funda pelo ritmo de uma duração, sobre um tempo de que se apropria, mas antes sobre uma venda. Termo que poderia servir para designar, como bem analisou Henri Lefebvre, um escoamento temporal "sem referente". "A venda, diz ele, troca segundo a intenção e a hora. Viva, alegre, para informar ou distrair, quando nos preparamos para o trabalho: a manhã. Doce, afetuosa para o retorno do trabalho e o tempo de repouso, a noite, o domingo" ${ }^{\prime 10}$.

A mídia procura, assim, dar uma imagem exata do cotidiano, do dia-a-dia, reconstruído. Pleno de energia pela manhã, pleno de fadiga à noite, opondo a semana ao final de semana, o dia e a noite etc... Todas estas reconstituições do vivido, longe de serem fiéis, criam uma tensão artificial a mais, uma divisão suplementar na vida social. Esta simulação dos tempos do cotidiano pela mídia, e é disso mesmo que se trata, de uma simulação, reforça, ainda mais, a abstração do tempo fluido, contínuo, que vem assegurar a transparência do planeta, que se repete indefinidamente em si mesmo, reconstruído por pequenas variações, e que se dilata e se reduz à vontade.

As características daquele tempo parecem ser contraditórias, ponto por ponto, em relação aos tempos ritmados e ritualizados da democracia, tempos descontínuos, tempos de procedimentos, tempos concretos e localizados, tempos opacos e difíceis de coordenar, tempos controláveis por regras (o judiciário ou as eleições, como qualquer decisão administrativa), tempos, em suma, que nem se dilatam e nem se reduzem à vontade, pois este tempo não é maleável por decisões ou intenções individuais já que ele é, coletivamente e historicamente, instituído.

Estes dois tempos midiáticos e democráticos são, neste ponto, distintos: eles não parecem ser capazes de entrar em contato um com o outro. Parece se instalar uma diferença irredutível de mundo, mais do que uma simples oposição no interior desse mesmo mundo. E, no entanto, eles estão em contato e não se anulam mutuamente. Inicialmente, porque o calendário midiático se justapõe aos tempos e aos ritmos do trabalho e do repouso que escandem a vida cotidiana. Da mesma forma que, anteriormente, o calendário pritânico de Clístenes se justapunha aos ritos do calendário lunar, mas também 
se misturava a ele, os horários dos telejornais, os da imprensa, os da telenovela em torno dos quais se repartem os horários de trabalho, todos estes tempos de escuta, não só se justapõem ao tempo democrático, como também o integram: a greve da televisão incomoda, profundamente, o uso do tempo. Os dois tipos de temporalidades se influenciam, pois, reciprocamente. Como? Até que ponto? Questões a respeito das quais nós tentaremos dar uma resposta na segunda parte.

\section{Democracia e mídia: os tempos que interagem}

Nós analisaremos aqui, sucessivamente, a influência do tempo das mídias na democracia (A) e a influência dos tempos democráticos nas mídias (B).

\section{A) A temporalidade das mídias influencia a democracia}

Nós já mostramos os efeitos das práticas midiáticas na democracia: efeito de engrandecimento do herói, esportista ou artista, do vilão, do ladrão etc... e isto, em detrimento das estruturas; debates reduzidos em fórmulas simplificadas, suavização e polimento em excesso (já que a televisão está presente nas salas, em nossa intimidade). Eu mencionaria, ainda, a televisão cerimonial, magistralmente analisada por Dayan e Katz, que remete à história da televisão, mas uma história com $\mathrm{H}$ maiúsculo, através de gravuras, pinturas próprias dos manuais do primário ${ }^{11}$. Eu desejo concentrar a atenção aos fenômenos mais recentes, ligados à multiplicação dos canais ditos "hertzianos" que já são bem mais numerosos do que no passado, sem falar das novidades introduzidas por satélites e a digitalização.

Pensemos, inicialmente, na meteorologia: ela cobre todos os lugares, várias vezes ao dia, em todos os canais e nos indica globalmente, para além do território nacional e mesmo dos países vizinhos (Itália, Grã-Bretanha, Bélgica, Alemanha), o tempo que faz e que fará em todas as grandes regiões do mundo. Todos estes tempos, em todos os sentidos do termo, nos são dados ao mesmo tempo, como em um espaço unificado, feito de espaçostempos justapostos-simultâneos. Nós sabemos, de agora em diante, com dias de antecedência, que o tempo que fará amanhã em Bouches du Rhône depende do tempo que faz, hoje, na Bretagne, o qual depende das perturbações do Atlântico no Oeste, etc... É a interdependência dos tempos e dos espaços que contribui para a visão unificada do planeta.

Visão que a Internet amplifica, através da facilidade e da frequiência das nossas comunicações. Assim, uma pequena vila perto de Tóquio pode se tornar mais importante do que Marseille... se as comunicações que se recebe ou se envia tem um volume mais significativo. Os mapas geográficos, e também os do tempo, são modificados. Será, talvez, mais demorado contatar meu amigo que está a três ruas daqui, se ele não tem fax, do que meu correspondente em Tóquio, desde que tenha fax, modem e-mail, etc...
Outra unificação, a que instaura uma visão ampliada da natureza. Pois a natureza não é apenas o tempo que é feito ou o mapa dos contatos, é também os animais de todos os tipos, do menor ao maior, do mais familiar ao mais estranho, animais de todas as cores e de todas as formas na terra, no mar ou no céu de todas as regiões do globo. Sem falar das plantas. Pode-se prosseguir sem erro, no sentido de que há, diariamente, em vários canais, transmissões sobre animais, plantas ou paisagens de viagem tanto quanto transmissões de meteorologia. Aqui, ainda, se acha reforçada esta visão ampliada da Terra. Se nos concentrarmos nas manifestações culturais, mesmo fenômeno: atores e diretores, pintores, dançarinos, músicos, arquitetos nos apresentam suas obras junto a comentários, e contribuem com a criação progressiva de um espaço cultural único, homogêneo; é ainda uma visão ocidental que prevalece.

Uma outra homogeneização, ainda, a da técnica. Observemos que o avião é menos mostrado, salvo quando constitui objeto de uma pesquisa. Caso contrário, o avião é ausente. Vê-se Clinton entrar na passarela, e, ao se aproximar, é saudado entusiasticamente, etc... Ele chegou sem viajar. É que o deslocamento não colocou nenhuma espécie de problema. Ele é imediato, como na Internet, tomando, aqui, a televisão como modelo.

De maneira geral, a técnica nunca falha. Esta visão da técnica nos dá ainda a imagem de um mundo unificado: um progresso tecnocientífico na Europa afeta tanto os americanos e o mundo quanto um progresso nos Estados Unidos afeta os europeus e o planeta inteiro. $\mathrm{O}$ projeto Genoma é mundial, enquanto o acidente de um DC8 na Índia afeta a totalidade dos DC8 em testes no mundo inteiro.

As mídias contribuem, pois, para a ampliação do espaço e à criação de uma cultura comum. Observemos que eu não falei de política, para evitar as banalidades. O duelo Clinton-Starr está presente em todas as mentes, e o vestido de Monica não tem mais segredo para ninguém. Mas também um atentado terrorista em uma embaixada interessa o planeta inteiro, pois nenhuma pessoa está livre dos terroristas. Diana chorou a cântaros na maioria das casas pobres que visitou, a monarquia britânica é criticada no mundo inteiro e esta morte causa um choque maior que a de Madre Teresa.

Não se pode mais falar de um lugar preciso, de um território delimitado que se denomine Nação e sobre o qual haja uma democracia nacional. Esta democracia nacional e administrativa na qual nós nascemos aparecem aqui como um resíduo, minúsculo, arcaico, inútil. A natureza é uma, como as espécies animais ou vegetais, como a técnica e a ciência. O homem também é um, dentro de sua variedade de traços e de pigmentação. E, todavia, observa-se sempre a existência de barreiras, alfândegas, controles de fronteiras. Enquanto isso, fluxos eletrônicos e financeiros, atravessando o céu e ignorando os limites, modelando ao mesmo tempo as opiniões e as economias. Espécie de Electronicon ou Deus 
eletrônico sem face.

Vemos que as mídias não deixam de influenciar as mentalidades e as representações nacionais. No limite, neste contexto, democracia nacional não quer dizer nada. $\mathrm{O}$ que conta é uma democracia mundial em formação progressiva, às vezes balbuciante, às vezes bem pouco democrática. Mas não se pode seriamente negar a criação de um espaço-tempo planetário que tende a se homogeneizar. Tal é, ao menos, a versão maximalista, que sacode os imaginários.

Versão minimalista: a democracia nacional continua, mas parece curiosa. A exceção cultural exigida pela França parece bizarra, da mesma forma que a exigência britânica do retrato de Sua Majestade no Euro é incongruente. Existe, pois, nesta visão minimalista, um apelo aos governos nacionais a se exibirem como portadores de valores universais, de direitos do homem universal, de uma ecologia universal, de uma tecnociência universal a serviço de todos, sob pena de se tornar invisíveis ou inaudíveis. E este é o efeito direto das mídias nas democracias nacionais, mesmo que na prática aconteça o inverso: práticas de camuflagem, o que é próprio da ideologia.

Mas corrijamos o pessimismo subjacente às análises. Esta passagem de uma democracia nacional a uma democracia internacional, este alargamento do espaço democrático através do tempo midiático, não conduz que diluições, efeitos de superfície, apelos à publicidade. As transmissões de Marc Ferro são ao mesmo tempo sintomas e símbolos. Um canal franco-alemão suscita uma dupla atenção, simultânea dos alemães pelos franceses e dos franceses pelos alemães, o que é de uma importância extrema para a construção de uma opinião pública comum em um espaço europeu.

\section{B) As temporalidades da democracia influenciam as mídias}

Passemos, antes, ao pluralismo. A técnica permitiu a multiplicação dos canais generalistas. Não é o pluralismo democrático que está em causa, ainda mais que esta multiplicação não serve, necessariamente, ao pluralismo de opiniões se os canais são submetidos aos imperativos comerciais de grande audiência, opinião esquemática e policiada. O mesmo vale para os canais temáticos que podem melhorar a educação, reforçar a cultura, suscitar o interesse pelas artes e, assim, desenvolver uma informação de bom nível. Estes canais plurais, ratificados pela técnica, podem, pois, aumentar o nível de consciência crítica das populações se permanecerem fruto de produtores e programadores críticos. Interação nos dois casos. Igualmente, as contestações pela imprensa das decisões governamentais ou judiciárias reforçam mais a democracia pluralista que reforça, por sua vez, o pluralismo das mídias.

Mas eu desejo concentrar minha análise sobre dois aspectos importantes: os efeitos imprevistos do uso imoderado das mídias e o código de deontologia dos jornalistas.

\section{C) Os efeitos imprevistos do uso imoderado das mídias}

O que Kennett Starr não viu, não mais que a insípida maioria republicana da Câmara dos representantes, menos ainda que a grande maioria da imprensa americana, é que as mídias não são todo-poderosas. As pesquisas continuam favoráveis a Clinton e o são cada vez mais, a tal ponto que ele não perdeu as eleições de novembro. Vexame das mídias. Os políticos republicanos são derrotados e Starr perdeu, neste momento, sua batalha midiática (mesmo se lhe restam armas potentes de ordem judiciária).

\section{Os tempos descontínuos, heterogêneos, confusos da democracia os transportam, sempre, contra o tempo homogêneo da mídia.}

Sem dúvida, Clinton ainda está em dificuldade e não se pode prever o futuro. Mas a repetição obsessiva durante meses e, em particular, por três vezes em agosto, setembro e outubro (rapport Starr e comparecimento do presidente diante do grande júri, e, de novo, o caso Starr mais desenvolvido) teve por efeito consolidar sua posição. A repetição é uma das características comuns das mídias e um elemento essencial do automatismo midiático: tautologias repetitivas e autismo que eu tinha reduzido a tautismo na minha Critique de la communication ${ }^{12}$.

Mas aqui esta repetição se torna uma obsessão - sexual - de Starr, que converge com a obsessão das mídias concorrentes. Tudo dito e repetido para evitar que os desmentidos e as tréplicas estejam só no jornal vizinho. Subestimou-se, claramente, o nível de consciência crítica dos americanos. Não é o caso, como se disse, de que os americanos tenham se tornado menos puritanos, é que a imprensa e a televisão, as rádios e a Internet, desempenharam um papel massivo que suscitou uma repulsão.

Isto não é novidade. Lembremo-nos da França do general De Gaulle, em 1965. Estupefação geral e, em particular, dos gaulistas. Mas é que, durante sete anos, a televisão do monopólio tinha, de forma ultrajante, favorecido o General e a sua política. Foi suficiente para que, por razões jurídicas de campanha eleitoral, outros candidatos aparecessem, em particular Jean Lecanuet e François Mitterrand, e para que a imagem de De Gaulle se fragilizasse. Mais tarde, a direita e a esquerda se lembrarão deste episódio. A saturação é um procedimento perigoso.

Os tempos democráticos de uma opinião plural, crítica, têm sempre razão em relação ao tempo homogêneo, saturado e saturador, irrespirável da prática midiática 
homogênea. A vitória da esquerda plural na França ou de Schroeder, na Alemanha, é, em parte, a vitória contra a imprensa dita única. Os tempos descontínuos, heterogêneos, confusos da democracia os transportam, sempre, contra o tempo homogêneo da mídia.

\section{D) $\mathbf{O}$ código de deontologia dos jornalistas}

Trata-se de uma serpente do mar que reaparece, continuamente, há decênios. Mas hoje, toma outra configuração, sem que os próprios profissionais o saibam. Sem dúvida influenciada pela imprensa televisiva, a imprensa escrita - e a mais honorável - acaba se excedendo, como no episódio de Timishoara, no qual jornalistas escreveram em seus jornais que viram - com seus próprios olhos - os massacres de Timishoara. Eles não viram que a televisão mundial repetia a televisão romana e suas montagens delirantes. Nós temos na lembrança que a maioria da imprensa escrita norte-americana condenou Clinton em nome dos ditos princípios jurídicos que traduziam uma inquisição de ordem moral e uma escolha política. Mas estas derrapagens não são apenas norte-americanas. Deve-se lembrar que em 1998 o Le Monde consagrou vários artigos de insinuação sobre o presidente do Conseil Constitutionnel, Roland Dumas. Estes artigos não tinham nenhuma prova nova (e nem podiam confirmar qualquer prova antiga). Mass Roland Dumas já fora julgado pelo jornal Le Monde, que, em editorial, pedia a demissão dele, mesmo sendo inocente, pois sua imagem suja (por quem?) afetava a instância constitucional suprema da República.

\section{Os ritos se tornam laicos e são ligados a este mundo do trabalho do qual o ritmo depende.}

Curiosos princípios. É preciso vender jornal. Le Monde se corrige. Aplaude-se. Mas a que preço?

Todas estas questões de imitação das mídias audiovisuais pela imprensa escrita, indevida mas que vende, até a precariedade no início de carreira dos jornalistas, clamam por um código de deontologia que protegeria os próprios jornalistas contra os excessos de seus redadores-chefe.

O tempo da democracia está contido neste código futuro. O tempo democrático é feito de formas preventivas. Se um código se faz necessário é para introduzir na imprensa procedimentos democráticos. Até aqui era em nome da liberdade de imprensa que os jornalistas recusavam o código de deontologia, e é para permitir maior espontaneidade ainda, mais transparência, mais instantaneidade. Mas a questão se deslocou hoje em dia. É em nome da liberdade do jornalista, condição da liber- dade de imprensa, que um código de deontologia deve nascer, pois nós conhecemos, nesse meio tempo, todos os excessos da transparência e de instantaneidade. Os jornalistas se acharão protegidos contra as pressões de seus diretores. As regras comuns e aceitas permitirão, pois, que se reforce a liberdade de imprensa. Belo exemplo em gestação de uma influência do tempo democrático sobre o tempo das mídias. Pois um código de deontologia instalará seus ritos e ritmos, como uma constituição que seria aceita por todos.

\section{Conclusão}

Nós vimos como o rito e o ritmo estão no centro das temporalidades diversas que constroem nossa apreensão do mundo, e assim, do planeta. Eu tentei mostrar que estas temporalidades se compõem mutuamente mais do que se opõem entre si, indo, assim, na contracorrente de certos postulados.

Na verdade, o que nós revelamos nesta rápida análise são as formações heterogêneas aliando um traço e seu contrário, como, por exemplo, esta justaposição simultânea que caracteriza as temporalidades de Carros: justaposições porque são vividas por habitantes que tudo separa, mas simultâneas, pois elas são vividas no mesmo tempo civil que as legaliza. Ora, a essa justaposição simultânea, que é aquela que nós vivemos no cotidiano, corresponde na mídia uma continuidade cortada e entrecortada, aquela do fluxo incessante de informações, sem cessar, interrompidas e comprimidas pela divisão em fatias de horários e a formatação dos eventos. Enfim, à ritualização religiosa e social dos tempos civis que concerne sobretudo dias especiais (as festas, os feriados, as "pontes") corresponde, na mídia, à ritualização dos momentos de uma mesma jornada.

Sem dúvida, há um resvalamento significativo que vai da simultaneidade de uma presença vivida a um conceito mais abstrato que é aquele de uma continuidade imóvel. Resvalamento também do rito ligado à religião ou às estações, ou ainda aos grandes acontecimentos históricos (queda da Bastille, armistício) a uma ritualização sem referente... traço que eu qualifiquei de rito sem ritmo. Assim, nós iríamos na direção de uma abstração cada vez mais marcada, sem que nos déssemos conta, aliando, em um mesmo movimento, o concreto do tempo enraizado em seus próprios limites e a abstração de um tempo que respeita, ao simulá-los, as ritualizações habituais.

Um resvalamento contínuo afeta, assim, nosso sentimento do tempo: um "calendário" - ou seja uma medida pública do tempo - no lugar de outro, mas guardando sempre alguma coisa daquilo de que se substituiu. E este deslizamento, como eu acabei de observar, parece se orientar em direção do mais concreto ao mais abstrato. Assim o fora na Gécia democrática, onde, ao instituir-se a isonomia do tempo e do espaço, regulou-se o tempo dos pequenos reis ligados à sua terra e dos ritos lunares no passado distante. A cidade, por sua vez, mantinha seus próprios ritos e celebrações em justaposi- 
ção aos ritos mais antigos. A mesma coisa se produziu na Revolução Francesa: abstração de uma língua comum tomando o lugar dos dialetos e das línguas regionais, instalação de uma divisão abstrata do território e, finalmente, também a instalação de um calendário uniformizado, republicano, deixando as festas e as comemorações locais no seu ritmo antigo, compondo uma espécie de mistura em que se alternam ritos religiosos e republicanos...

Todavia, para a vida do trabalho, a preocupação de igualdade predomina, preocupação que leva à abstração das condições locais irregulares. Os ritos se tornam laicos e são ligados a este mundo do trabalho do qual o ritmo depende. Mas o deslizamento não terminou: ao lado desse calendário abstrato, mas do qual nós vivemos nossas singularidades locais e religiosas, entra em cena um outro tempo ainda mais abstrato, aquele das mídias de telecomunicação que interpelam o tempo dito "real", ou seja um suposto imediatismo, o planeta inteiro. Ora, sabe-se, e eu creio ter mostrado acima no exemplo de Carros, que a temporalidade concretamente vivida está ligada a uma localização (a região, o país, a nação, mas também a instituição, o métier etc.). Esta localização ou particularização do tempo faz contrapeso à uniformização do trabalho: localização e uniformização desempenham uma divisão a duas vozes.

Com a entrada em cena das temporalidades midiáticas, nós temos uma justaposição de um tempo unificado, deslocado, do qual toda irregularidade ou singularidade desapareceu, no tempo misto e plural, dotado de irregularidades, que é nosso tempo republicano. Este tempo midiático, pois, desempenhará então, em face do calendário republicano, o papel que tinha o calendário pritânico em relação ao calendário lunar. É o tempo republicano que se torna, em relação ao tempo midiático, uma espécie de "lua velha", pois guarda um princípio ritual religioso no seu fundo, e é o tempo abstrato de uma isonomia total, que vai, então, até apagar toda marca de individualidade nacional e toda fronteira, que retoma o papel de tempo unificador desejado por Clístenes. Neste jogo de vai-e-vem e de sucessivas substituições, nós podemos deixar correr nossa imaginação...

Haverá, em um futuro indeterminado, um processo do mesmo tipo, uma abstração maior, ainda inimaginável hoje em dia, para colocar o tempo midiático no ranking da velha lua? A menos que, por um costume histórico do eterno retorno, e por preocupação de se preservar esta parte íntima do tempo concretamente vivido na diferença, nós retomemos a ritualização das estações e dos dias... Se nós tomássemos o tempo de sonhar o tempo? afamecos

\section{NOTAS}

* Texto apresentado no IX Seminário Internacional da Comunicação - PUCRS/novembro de 2007.

1. Duas noç̃̃es que os filósofos e os antropólogos conhecem bem. Bachelard, por exemplo, que, depois de sua "Dialectique de la durée ", desejava uma ritmanálise. Idéia retomada por Henri Lefebvre.

2. Aristote Physique, Livre IV, 11 .

3. Aristote, Physique, 10.

4. Ver a respeito Pierre Levêque et Pierre Vidal-Naquet, Clisthène l'Athénien, Macula, 1964.

5. Mais tarde transformado pelo papa Gregório XIII, daí nosso calendário gregoriano. Ver Paul Couderc, Le calendrier, QSJ, 1948.

6. As afinidades, a moral e o tempo, pesquisa dirigida por Lucien Sfez, Credap, 1980.

7. Henri Lefèbvre, Eléments de rythmanalyse, Ed. Syllepse, 1991, p 65.

8. Ibidem, p 67 et suivantes.

9. Dans ses "Leçons pour la phénoménologie de la conscience intime du temps".

10. Henri Lefebvre, Ibidem, p 68.

11. Voir Dayan et Katz, La télévision cérémonielle, PUF, 1996.

12. Le Seuil, 1ère édition 1988, 3ème édition 1992. 